\title{
SYAIR DALAM PENDIDIKAN ISLAM MADRASAH AS'AD JAMBI SEBERANG 1944-1970
}

\author{
Nirwan II Yasin ${ }^{1}$, Siti Syuhada ${ }^{2}$ \\ ${ }^{1}$ Universitas Jambi, Indonesia, e-mail:nirwan87@unja.ac.id \\ ${ }^{2}$ Universitas Jambi, Indonesia, e-mail: syuhadasiti2008@gmail.com
}

\author{
(c) (7) (?) \\ (C)2020 by the authors. Submitted for possible open access publication under the terms and conditions \\ of the Creative Commons Attribution-ShareAlike 4.0 International License (CC-BY-SA) \\ license (https://creativecommons.org/licenses/by-sa/4.0/) \\ do DOI : http://dx.doi.org/10.30983/it.v4i2.3544
}

\begin{abstract}
Researchers and academicians have indeed done a lot of researches in Jambi. The aspects of the life the society of Jambi Seberang in all any studies have been carried out, one of them is historical studies. The research process was also carried out by involving in-depth studies which became a reference to previous studies in this research. The rbyme is one of the Jambi education learning process in the Jambi Seberang area that still needs to be revealed. This awareness also wants to be built in the midst of the many educational patterns that have been adjusted during the times. Rhyme in the 20th century has become a powerful method, in addition to the fact that the people of Jambi have already recognized the repertoire of this rbyme as part of the cultural speech of the people. One of the teachers who uses rbyme in his studies is teacher Abdul Qodir Ibrabim. This research was using historical methods, namely: Heuristics, criticism, interpretation, and historiography. The disclosure was made so that all forms of educational changes that exist in Jambi society can be appointed as the identity of the Jambi Sebrang society. This disclosure was made in the Jambi Seberang area, which is the first area of Islamic education in Jambi. This investigation tries to explain rhyme in the Islamic education of Jambi community, and the dynamics of its development process.
\end{abstract}

Keywords: Rhyme; Islamic Education Methods; Abdul Qodir Ibrabim

\begin{abstract}
Abstrak
Peneliti dan akademisi memang telah banyak melakukan penelitian di Jambi. Aspek sisi kehidupan masyarakat Jambi seberang dalam kajian apapun telah dilakukan. Salah satunya kajian sejarah. Proses penelitian ini pun dilakukan dengan melibatkan kajian yang mendalam yang menjadi referensi tinjauan terdahulu tentang penelitian ini. Syair dalam proses pembelajaran pendidikan Jambi di wilayah seberang Kota Jambi yang masih perlu untuk diungkap. Kesadaran ini juga ingin dibangun di tengah banyak pola pendidikan yang sudah disesuaikan pada perkembangan zamannya. Syair pada akhir abad 20 menjadi metode yang ampuh, disamping memang secara garis besar masyarakat Jambi telah mengenal khasanah syair ini sabagai bagian dari tutur kebudayaan masyarakatnya. Salah satu Tuan guru yang mengunakan syair dalam pembelajarannya yaitu Tuan guru Abdul Qodir Ibrahim. Dalam penelitian ini menggunakan metode ilmu sejarah yaitu: Heuristik, kritik, intepretasi, dan historiografi. Pengungkapan ini dilakukan agar segala bentuk proses perubahan pendidikan yang ada dalam masyarakat Jambi bisa diangkat sebagai identitas masyarakat Jambi. Pengungkapan ini dilakukan di wilayah Jambi Seberang yang merupakan wilayah pertama pendidikan Islam di Jambi. Dalam penelitian ini mencoba menjelaskan syair dalam pendidikan Islam masyarakat Jambi, dan dinamika proses perkembangannya.
\end{abstract}

Kata Kunci: Syair; Metode Pendidikan Islam; Tuan Guru Abdul Qodir Ibrahim .

\section{Latar Belakang}

Bicara tentang Jambi Seberang sebagai kajian sejarah, telah cukup banyak penelitian yang dilakukan untuk mengungkap wilayah ini. Nyaris seluruh aspek masyarakatnya telah dikaji baik yang dilakukan oleh peneliti dari dalam atau dari luar Jambi. Salah satunya adalah kajian pada aspek pendidikan yang ada di Jambi Seberang. Uniknya pendidikan yang diciptakan di kawasan itu hadir dari kesadaran bersama 
atas pentingnya sebuah identitas keagamaan yaitu agama Islam.

Pendidikan yang dikembangkan di sana disesuaikan dengan konteks masyarakat Jambi. Masyarakat ini diketahui memiliki kesadaran penuh bahwa Islam agama yang bisa mengubah struktur yang sudah ada. Konsep yang digunakan dengan segala pemahaman adat yang melekat di dalamnya justru mengikut ketika dikembalikan ke rujukan agama sebagai penentu akhir keputusan.

Wilayah Jambi Seberang sebelum menjadi wilayah pendidikan Islam, merupakan Kampung Pecinan. Datuk Sintai merupakan tokoh yang mendapat restu dari Kesultanan Jambi untuk membuat perkampungan itu. Pedagang Cina yang pertama menetap di Kampung Pecinan adalah Sin Thay. Ia adalah seorang penganut Islam. Sin Thay menikah dengan Nyai Resik, putri Sultan Suto Ingologo (1610- 1640). Ia diberi gelar datuk, sehingga terkenal dengan nama Datuk Sin Thay. Kemudian, Sultan memberinya tanah apanage yang terletak di daerah seberang dan berhadaphadapan dengan keraton. Datuk Sin Thay pindah ke seberang bersama keluarganya dan menetap di tanah apanage, hadiah dari mertuanya. Para pedagang Cina mengikuti jejak Datuk Sin Thay untuk menetap di daerah Seberang, sehingga dikenal dengan nama Kampung Pecinan.

Daerah itu terletak di sisi utara Sungai Batanghari. Selain membangun rumah di sisi Sungai Batanghari, para pedagang Cina juga membuat rumah rakit di pinggiran sungai yang sama. Posisi rumah yang dibangun di daratan sejajar dengan pinggir sungai.

Kesamaan agama para pedagang Cina dengan penduduk pribumi memudahkannya untuk diterima, baik oleh pihak kesultanan maupun masyarakat Melayu-Jambi. Bahkan,

1 M.A.P.Meilink-Roelofsz, Perdagangan Asia dan Pengarub Eropa di Nusantara Antara 1500-1630, Diterjemabkan Oleh Aditya Pratama (Yogyakarta: Ombak, 2016), 126. pedagang Cina ditunjuk oleh Sultan Jambi sebagai pedagang perantara dalam perdagangan dengan bangsa asing lainnya, seperti Portugis, dan Spanyol. Mereka mengumpulkan berbagai komoditas daerah Jambi, seperti lada, karet hutan, dan rotan. Lada merupakan komoditas utama Jambi yang dijual kepada pedagangpedagang asing. ${ }^{1}$

Selain keturunan Cina, penghuni Kampung Pecinan adalah keturunan Arab. Mereka membangun perkampungan sendiri di daerah Kampung Pecinan. Kampung keturunan Arab itu bernama Kampung ArabMelayu. Keberadaan mereka di Jambi diperkirakan sudah ada sejak abad ke-15. Hal ini terlihat dari keberadaan pemakaman ArabMelayu dan salah satu dari pemakaman itu bertarikh tahun 1400-an Masehi. Salah seorang tokoh keturunan Arab adalah Habib Husein Baraqbah. Dia datang ke Tanah Pilih dalam rangka berdakwah dan menjadi orang Arab pertama yang berada di Kesultanan MelayuJambi. Habib Husein Baraqbah kemudian menikah dengan putri Nyai Resik, Datuk Shin Thay.

Selain Habib Husein Baraqbah, keluarga Al-Jufri juga dapat disebut sebagai keluarga Arab yang cukup terkenal dan memiliki kedekata.n khusus dengan Sultan MelayuJambi. Melalui perkawinan pula orang Arab masuk ke dalam keluarga kelas bangsawan Melayu-Jambi dan kemudian diberi kedudukan penting. Suku mereka ditentukan berdasarkan suku istrinya. Misalnya Said Idris yang kemudian diberi gelar Pangeran Wirokusumo, seorang Arab yang berpengaruh yang menikah dengan anak perempuan Sultan Thaha Saifuddin dan Sultan Akhmad Nazaruddin. ${ }^{2}$

Dalam perkembangannya menjadi wilayah keagamaan yang kuat ketika wilayah tanah pilih kesultanan Jambi di kuasai belanda. Kesultanan

${ }^{2}$ Ujang Hariadi Lihat Lindayanti, H. Junaidi T. Noor, Elsbeth Locher-Scholten, Sumatraans Sultanaat en Koloniale Staat: De Relatie Djambi- Batavia (1830-1907) En Het Nederlandsche Imperialisme (Leiden: KITLV, 1994), 132. 
yang tidak mau bekerja sama seperti Sultan Taha Syaifudin harus masuk ke huluan pedalaman Jambi. Kondisi ini terjadi ada kesultanan yang di bentuk belanda yaitu kesultanan hilir dan kesultanan hulu yang di akui oleh masyarakat Jambi. Kondisi ini membuat ada semacam perubahan baru terhadap Jambi seberang yang sebelumnya sebagai perkampungan pecinan berubah menjadi ruang untuk menumbuhkan nilai islam yang kuat dalam perkembangannya. Dan membuat perkembangan ini berimbas pada munculnya para intelektual ulamam untuk hadir disana dan dalam perkembangannya membuat lembaga pendidikan. Pada akhirnya wilayah Jambi seberang menjadi selain pusat keislaman yang kental di luar kesultanan juga pusat pendidikan Islam yang berpengaruh di Jambi.

Perkembangan pendidikan Islam di Jambi seberang dalam perkambangannya, pembelajarannya banyak metode yang digunakan Tuan Guru. ${ }^{3}$ Salah satunya dengan membuat pola pembelajaran yang disesuaikan dengan karakteristik masyarakat yaitu bersenandung dengan polarisasi seperti berselokoh dalam kehidupan sehari-hari. Dalam konteks ini pemahaman bersyair pun dilakukan dalam masyarakat Jambi masa lampau.

Hal ini tidak lepas dari proses pembiasaan masyarakat yang selalu melantunkan kejadian dan keadaan yang ingin diungkap. Hal ini dilakukan untuk menghibur dalam keadaan tertentu dan menunggu sesuatu, maka muncullah kegiatan bersenandung. Dalam perkembangannya disadari atau tidak menjadi kebiasan yang turun temurun terjadi dan mengakar di dalam masyarakat Jambi.

Kondisi ini membuat pola mempelajari agama mengalir dengan cara-cara dan kebiasan yang dilakukan sesuai kebiasaan masyarakat Jambi. Pemahaman aturan dalam pendidikan

3 As’Ad Isma, "Pergeseran Peran Sosial Tuan Guru dalam Masyrakat Jambi Seberang," Kontekstual Jurnal Penelitian Sosial Keagaman 20, no.1 (2005): 6. itu sendiri dipakai dalam kehidupan masyarakat Jambi Seberang berdasarkan adat dan kebiasaan. Kemudian berubah seiring perjalanan waktu dengan konsep dan pemahaman baru yang bersumber dari ajaran Islam. Pemahaman dan tata cara yang baru dalam penerapan pendidikan ini bercampur baur sedemiakian rupa sehingga menyentuh dengan aturan lama yaitu yang ada dalam adat.

Proses percampuran ini dalam perkembangannya secara pelan tapi pasti bergerak dan pada pelaksanaan nya tanpa menimbulkan gejolak yang berarti dalam masyarakat Jambi itu sendiri. Jika dalam aturan adat ada yang bertentangan dengan syara' maka adatlah yang harus mengalah, sebab apa yang sudah digariskan dalam pemahaman Islam harus dijabarkan oleh adat dalam setiap aktifitas masyarakat dalam kehidupan sehari-hari.

Maka ketika tindak lanjut dari aktualisasi pelaksanaannya dalam kehidupan sehari-hari adat yang salah, dan selalu bertentangan, maka secara otomatis adat akan mengalah dengan sendirinya dengan pemahaman itu sendiri. Begitupun dengan proses percampuran yang damai antara pendididkan yang dibuat oleh adat dan di terjemahkan dalam pemahaman salah satunya pendidikan Islam yang di ajarkan dalam masyarakat Jambi Seberang. Menyesuiakan dengan polarisasi yang sudah di gariskan oleh ajaran ajaran Islam. ${ }^{4}$

Percampuran ini dilakukan baik berupa pendidikan yang dilakukan dalam keluarga atau dalam pendidikan yang dilakukan dalam ranah sebauh lembaga pendidikan. Pengaruh yang memasukkan kebiasan bertutur dalam lembaga pendidikan terjadi. Keadaan ini terjadi ketika suatu wadah pendidikan yang tersistem dan di sepakati baru memulai pada tahun 1915. Tuan Guru, elit ulama Melayu-Jambi melalui "Perkumpulan Tsamaratul Insan" mendirikan

${ }^{4}$ Hendra Irawan Ika Selviana, "Nilai Nilai Moral dalam Syair Cinta Rasul Al-Busiry," Jurnal Al-Fathin 3, no. 2 (2020): 35 . 
madrasah-madrasah di Kampung Pecinan. Tuan Guru juga menjadi penggerak religiusitas kehidupan masyarakatnya. ${ }^{5}$

Kemudian, Kampung Pecinan berubah sebutannya menjadi "Serambi Mekah" Kota Jambi. Perubahan itu diiringi oleh perubahan fungsinya, yaitu dari ruang sosial-profan menjadi ruang sosial-sakral Jambi-seberang.

Salah satu tokoh yang memberi peran besar dalam pendidikan Jambi Seberang dengan metode bersyair nya adalah KH. Abdul Qodir Ibrahim. Beliau termasuk ulama yang produktif menulis salah satunya karya syair.

Kajian ini ingin menggali lebih dalam aspek-aspek apa saja yang terjadi dalam bersyair dalam pembelajaran masa akhir abad ke-20 dalam kegiatan pendidikan di Jambi seberang dan memperbandingkannya dengan sekarang, maka dari itu peneliti ingin mengetahui dinamika perubahan yang terjadi dalam pembelajaran bersyair yang masih efektik dalam kehidupan sekarang, sehingga merumuskan pertanyaan sebagai berikut: mengapa tuan guru Abdul Qodir Ibrahim memilih syair sebagai metode penyampaian pendidikan islam di Jambi; mengapa syair dipakai dalam pengajarkan pemahaman Islam, baik yang dilakukan di lembaga pendidikan atau dalam keseharian?

Penelitian ini secara umum bertujuan untuk mengetahui metode pembelajaran syair dan aspek menggali kearifan lokal masyarakat Jambi. Selain itu mengungkap peran bersyair dalam kehidupan masyarakat Jambi Seberang dalam lembaga pendidikan. Lokasi penelitian yaitu di Jambi Seberang Kota Jambi. Secara khusus, penelitian ini bertujuan untuk menginventarisasikan pola pembelajaran syair sejauh mana bisa diterapkan dalam pembelajaran lain selain pembelajaran agama Islam. Untuk mengetahui aspek apa sajakah yang terdapat dalam pembelajran syair untuk dilakukan sekarang dan sejauh mana dapat memberi pengaruh dalam pembelajaran yang dilaksanakan hari ini.

Urgensi Penelitian yaitu pentingnya suatu kearifan lokal dalam pembelajaran untuk mengetahui sejauh mana pembelajaran ini sangat efektif dan bagaimana bisa diterapkan pada pendidikan sekarang. Selain itu menjadi bagian dari eksistensi suatu bangsa bahwa dalam model pembelajaran syair juga punya peran besar dalam pendidikan.

Kebiasaan masyarakat yang acuh terhadap tinggalan sejarah terutama tinggalan syair masa lalu yang luput diketahui generasi sekarang membuat menjadi salah satu penyebab tinggalan sejarah tersebut semakin terpinggirkan. Anggapan bahwa tinggalan masa lalu dengan konsep pendidikan yang di lakuakan masa lampau tidak sesuai dengan zaman juga mengancam eksistensi tinggalan sejarah. Padahal, tinggalan sejarah dalam pola pembelajaran bersyair dapat menjadi sumber utama sejarah dalam mengungkap indentitas sejarah pendidikan Jambi. ${ }^{6}$

Jika potensi sumber daya alam semakin lama semakin tergerus justru potensi tinggalan sejarah dan kebudayaan dijaga dan di pelajari menjadi untuk menjadi identitas masyarakat dari satu generasi ke generasi berikutnya. Untuk itu, diperlukan strategi agar pelestarian dan pemanfaatan tinggalan sejarah berupa syair dilestarikan dan dipelajarai untuk mencapai hasil yang maksimal untuk identitas bangsa.

Namun sebelum sampai tahap itu, upaya pemetaan tinggalan sejarah jambi dalam hal ini tulisan-tulisan yang dihasilkan ulama Jambi harus segera dilakukan. Hal itu dilakukan agar kita dapat menemukan cara pelestarian dan pemanfaatannya yang berbasis penelitian. Sehingga hasil dari pemetaan ini akan
${ }^{5}$ Masitoh, "Tsamaratul Insan dan Pengembangan Pendidikan Islam di Kota Jambi (1915- 1972M)," Thesis UIN Sunan Kalijaga Yogyakarta (2018), 56.
${ }^{6}$ Aliyas, "Meninjau Kembali Sejarah Masuknya Islam di Jambi. Media Akademika” 28, no. 3 (2013): 12. 
mendapatkan gambaran yang pasti mengenai potensi tinggalan sejarah apa yang akan di lakukan dan diketahui oleh generasi setelah itu.

Penelitian ini mencoba menggali lebih lanjut tetang syair dalam pembelajaran lembanga pendidikan Islam di Jambi Seberang. Tentang perkembangan syair dalam lembaga madrasah dalam sudut pandang sejarah sosial. Sejarah sosial sendiri mencoba dalam sudut pandang, melihat gejala yang terjadi dalam masyarakat.

Konsep ini melahirkan kondisi secara mendalam kehidupan sosial komuditas atau kelompok. Dengan penulisan dan dalam sudut pandang sejarah diharapkan dapat menterjemahkan berbagai macam penjelasan yang berhubungan dengan hal-hal menyangkut permasalahan dalam penelitiannya.

Pendekatan sosiologis juga dilakukan peneliti dalam menjelaskan sejarah perkembangan syair dalam lembaga pendidikan di Jambi Seberang Kota Jambi. Pendekatan sosiologis merupakan studi tentang kehidupan manusia tentang peristiwa masa lalu. Selain itu sebagai kajian sejarah sosial yang mencakup golongan sosial yang berperan. Seluruh bagian ini menjadi kondisi yang tidak bisa di pisahkan dari kondisi sosial manusia.

Lembaga pendidikan dalam sejarah perkembangan Islam di nusantara memegang peranan yang sangat penting. Peranan ini penting dan sangat vital dalam menentukan dan membangun sebuah sikap membangkitkan nasionalisme bangsa Indonesia. Selain itu pendidikan Islam merupakan wadah perjuangan membangkitkan kebangsaan untuk menunjang dan memperoleh hasil besar mencapai kemerdekaan Indonesia. ${ }^{7}$

Aktivitas pendidikan dalam masyarakat Jambi Seberang dalam perkembangannya, pada awalnya memang dilakukan diluar pendidikan madrasah. Seperti dari rumah ke rumah aktivitas masyarakat atau mesjid. aktivitas pengajaran Islam dilakukan dari rumah ke rumah ini dipelopori oleh Tuan Guru yang dianggap memiliki pengetahuan yang sangat luas dari segi ilmu agamanya.

Penjelasan tentang lembaga pendidikan Islam populernya dengan istilah pesantren, lembaga pendididikan di wilayah alam minangkabau lebih dikenal dengan pemahaman suraunya. Sedangkan Jambi sendiri pembelajaran tradisionalnya yaitu sekolah madrasah.

Pada hakikatnya dalam menjelaskan bagian kondisi sosial pengaruh besar sejumlah aktor individu yang saling berhubungan dalam situasi yang setidak-tidaknya memberikan pengaruh bagian lingkungan dari aspek secara fisik. Aktor-aktor yang memiliki dan memberikan perhatian dan dorongan besar yang memberikan dampak kecenderungan tersebut. ${ }^{8}$ Selain itu juga dalam memberikan pengaruh besar dan mengoptimalkan sebuah pertemuan yang terwujud dalam symbol dan tersusun secara kebiasan dan membentuk budaya dan kebiasaan masyarakat.

Syair yang dilakukan oleh Tuan Guru Abdul Qodir Ibrahim salah satu yang menjadi simbolisasi. Betapa pentingnya penggunaan syair ini dalam pembelajaran dalam lembaga pendidikan Jambi. Syair yang digunakan lebih memberi pengaruh terutama bagi pengamalan tauhid agar diterima dengan baik dan dilakukan dengan cara dan kebiasaan masyarakat Jambi itu sendiri. Agar proses pemahaman dan ajaran yang disampaikan bisa diterima secara keseluruhan maksud dan tujuan ajaran tersebut.

Peran tuan guru dalam ranah pembelajaran punya peran yang besar. Tuan Guru dalam hal ini sama dengan Kiyai di jawa, atau Ajengan di daerah Sunda. Tuan Guru di Jambi merupakan

\footnotetext{
8 Soerjono Seokanto F, Sosiologi Suatu Pengantar (Jakarta: Rajawali Press, 1985), 59.
} Pendidikan Integratif di Sekolah, Keluraga dan Masyarakat (Yogyakarta: LKIS, 2009), 85. 
seorang yang alim (ahli agama) tempat bertanya atas masalah-masalah yang timbul. Selain itu juga tuan guru menjadi panutan masyarakat, diikuti, dipatuhi, juga sebagai pemimpin sosial yang di hormati. Oleh karena itu, kefanatikan agama mereka sering menjurus kepada fanatisme terhadap tuan guru.

Peran, fungsi dan kepemimpinan tuan guru pada masyarakat Jambi Seberang telah berlangsung lama melalui sejarah yang panjang. tuan guru adalah aktor yang penting dalam membentuk corak dan sistem sosial budaya masyarakat sehingga dapat dikatakan bahwa hampir semua nilai sosial budaya dan tradisi keagamaan yang berkembang sampai sekarang merupakan kontribusi, warisan yang terus terpelihara keberlangsungannya lewat fitur tuan guru tersebut.

Dalam hal ini, kharisma tuan guru tidak hanya didasarkan pada penguasaannya pada bidang keagamaan semata namun lebih dari itu kharisma jauh diukur dari kapasitas kehidupan sosial berupa prilaku, pandangan, sikap, kepedulian dan integritasnya dalam membina kehidupan masyarakat dilingkungan sosialnya. ${ }^{9}$

Kajian penelitan ini menggunakan metode sejarah. Menggunakan berbagai aspek secara bertahap dan dilakukan secara sistematis untuk penelitian dengan menghimpun bahan sumber penelitian, memperdalam kajian penelitian. Cara meggunakan tahapan sejarah berkaitan pada aktifitas yang sangat mendalam yaitu, Heuristik (Pengumpulan Sumber), kegiatan menghimpun bahan sumber sejarah. Data bukti-bukti sumber sejarah tersebut dibagi dalam beberapa jenis, yaitu tinggalan sejarah yang utama dan tinggalan sejarah pendukung bukti sejarah itu sendiri.

Sumber utama yang dapat di pakai dalam menjelakan syair dalam pembelajaran masyarakat Jambi seberang dan koleksi pribadi

${ }_{9}$ Abu Usman Bakar, "Pendidikan Islam di Jambi : Corak Madrasah dari Kebudayaan Masyarakat Seberang Kota Jambi," Disertasi PPS IAIN Syabid Jakarta (1985), 35. yang menyimpan tentang tulisan syair-syair tersebut. Selain itu wawancara lisan dilakukan dengan beberapa orang yang di anggap mengetahui perkembangan syair dalam pendidikan masyarakat Jambi seberang. Seperti Mudir tun guru yang ada di madrasah tersebut, ataupun para alumni pendidikan yang pernah mengenyam pendidikan dan tau tentang bersyair tersebut.

Tahapan pemilahan dan memberi kritikan atas sumber yang didapat. Kritik dibagi dua, pertama kritik ekstern yang digunakan untuk mengetahui otentisitas sebuah sumber. Untuk memastikan bahwa sumber itu otentik, sumber yang digunakan harus merupakan sumber yang dikehendaki, sumber harus asli atau tidak turunan, dan sumber harus utuh. Kedua, kritik intern yang diperlukan untuk mendapatkan kredibilitas atau kebenaran sumber. Caranya, sumber-sumber yang telah didapat saling dibanding-bandingkan satu sama lain sehingga dapat diperoleh sumber yang dapat dipercaya.

Lalu pada tahapan berikutnya dilakukan interpretasi (penafsiran) penelitian dalam interpretasi penafsiran ini menganalisa semua data yang di dapat dalam penelitian syair dalam masyarakat Jambi Seberang dalam pendidikan di abad ke 20. Selain itu tafsiran ini didapat untuk menafsirkan sumber yang di dapat agar menemukan variable yang sama dalam tafsiran temuan di lapangan. Penafsiran ini secara berturut-turut disusun untuk membangun sebuah data yang benar dalam menjelaskan sebuah peristiwa masa lampau dalam hal ini masyarakat Jambi Seberang masa abad ke-20.

Setelah itu barulah dilakukan tahap penulisan secara kronologis. ${ }^{10}$ Dalam penulisan ini juga akan membuka prespektif tulisan yang secara relevan bagaimana syair dalam pendidikan Jambi tersebut bisa dihasilkan, sehingga semua bentuk kondisi sosial dan aspek

${ }^{10}$ Sjamsuddin, Metodologi Sejarah Jakarta: Departemen Pendidikan dan Kebudayaan Direktorat Jenderal Pendidikan Tinggi, 1996), 67. 
pendukung dalam hal ini pendidikan bisa di pahami sebagai tulisan yang saling berhubungan satu dengan yang lain. Metode penulisan syair dalam pembelajaran pendidikan Islam dalam masyarakat Jambi Seberang abad abad-20 dapat ditulis secara baik dan mendalam sebagai sebuah tulisan sejarah.

\section{Perkembangan Pendidikan Islam di Jambi Awal Abad 20}

Proses pendidikan Islam di Kota Jambi dekade awal abad 20-an disebut dengan "Madrasah Tradisional". Madrasah tradisional menggunakan proses pembelajaran tradisional dengan sistem halaqah, mengkaji kitab kuning dan murid belajar di pondok dengan kyai sebagai tuan guru.

Daerah Jambi berdiri perhimpunan atau organisasi Islam yang bernama Perukunan Tsamaratul Insan. ${ }^{11}$ Organisasi ini dipelopori oleh beberapa masyarakat Jambi yang belajar di Mekkah kemudian pulang ke Jambi. Perukunan Tsamaratul Insan inilah yang nantinya mendirikan lembaga-lembaga pendidikan Islam di Kota Jambi.

Perkembangan Pendidikan Islam di Jambi dalam bentuk madrasah tradisional ini dipengaruhi oleh kepulangan empat ulama termasyur yang belajar ilmu agama Islam di Darul Ulum dan Madrasah Shaulatiyah Mekkah. Keempat ulama tersebut adalah Ibrahim bin K.A Majid berasal dari Kampung Tengah, Ahmad bin H Abd Syakur berasal dari Takhtul Yaman, Usman bin H Ali berasal dari Tanjung Johor dan Kemas H.M Shaleh bin Kemas H.M Yasin berasal dari Tanjung Johor. Keempat ulama ini merupakan murid dari H.A. Majid yang merupakan seorang ulama Jambi yang mengajar di Madrasah Darul Ulum di Mekkah. ${ }^{12}$

11 J.R. Chaniago Hartono Margono, Mujilan, Sejarah Sosial Kota Jambi: Jambi sebagai Kota Dagang (Jakarta: Departemen Pendidikan dan Kebudayaan, 1984), 90.

12 Adrianus Chatib, Kesultanan Jambi dalam Konteks Sejarah Nusantara (Jambi: Puslitbang Lektur dan
Mereka juga pernah menghadiri halaqah Ahmad Khatib Al-Minangkabawi pada tahun 1915. Ahmad khatib Al-minangkabawi di dalam halaqahnya tidak hanya mengajarkan ilmu-ilmu agama tetapi juga menumbuhkan semangat nasionalisme muridnya untuk melawan kolonial belanda dan reformisme Islam di Indonesia. Organisasi Tsamaratul Insan berdiri pada 10 September 1914 secara resmi dengan izin dari Residen Jambi no 1636 atas peran Sayyid Ali AlMusawwa. ${ }^{13}$

Tsamaratul Insan merupakan organisasi yang bergerak di bidang sosial keagamaan khususnya menangani masalah kematian. Organisasi ini bertujuan untuk menanamkan keyakinan atau aqidah islamiyah serta mempersatukan umat Islam di Jambi. Kemudian berkembang menjadi lembaga dakwah dan juga bergerak melawan kolonial Belanda melalui pendidikan. Sebab, pendidikan dapat menjadi wadah untuk membangkitkan semangat rakyat Jambi untuk melawan Belanda.

Lembaga pendidikan Islam yang berkembang pada awal abad 20-an di Jambi yang diprakarsai oleh para ulama yang tergabung dalam Organisasi Tsamaratul Insan adalah sebagai berikut: Madrasah Nurul Iman di Jambi Pesantren Nurul Iman didirikan pada tahun 1332 H (1914 M) oleh H. Abdul Samad, beliau merupakan seorang ulama besar di Jambi. Madrasah ini terletak di Kampung tengah.

Kitab-kitab yang dijadikan rujukan dalam proses pembelajran di Nurul Iman adalah Ajrimiah/Mukhtasar, Syek Khalid, Azhari, Qatrun Nada, Khudri ( Ibnu 'Aqil, Saafinatun Najah, Matan Taqrib/Fathul Qarib, Fathul Mu'in, Iqna, Wara', Lathaiful Isyarah, Lubhul, Jam'ul Jawami, Dardir, Matan Jauharul Maknun, Talkhish, Matan Sullam, Idhahul

Khazanah Keagamaan Badan Litbang dan Diklat Kementrian Agama RI dan Fakultas Adab IAIN Sultan Taha Saifuddin, 2011), 96.

${ }^{13}$ Masitoh, "Tsamaratul Insan dan Pengembangan Pendidikan Islam di Kota Jambi (1915- 1972M),” 87. 
Mubham, Ishaghuji, Sabban Al-Mawi, Matan Bina, Talkhisul Asas, Mattan 'Uzza, Kailani, AlMathub, Mathan Al-Bajuri, Matan As-Sanusi, Kifayatul 'Awam, Ad-Dusuqi, Al-Hudhuhi.

Madrasah Sa'adatu Darain Madrasah Sa'adatud Darain didirikan pada tahun 1915 oleh H. Ahmad Syakur. Madrasah Sa'datul Daraain terletak di Takhtul Yaman Beliau adalah seorang ulama termasyur di Jambi. Selanjutnya ada Madrasah Nurul Islam didirikan oleh H. Ahmad, Madrasah ini terletak di tanjung pasir. Menyusul kemudian Madrasah Djauharin Madrasah ini didirikan oleh $\mathrm{H}$. Abdul Majid pada tahun $1340 \mathrm{H}$ dengan jumlah murid yang termasuk banyak menuntut ilmu disana. Madrasah ini terletak di Tanjung Johor. $^{14}$

Lembaga pendidikan selanjutnya yaitu Madrasah As'ad, Madrasah ini didirikan oleh Kiyai Abdul Kadir Ibrahim pada tahun 1952. Madrasah yang tergolong baru ini menggunakan kitab-kitab keluaran Minangkabau. Selain itu, terdapat pula madrasah-madrasah di daerah Jambi yang berlainan nama dan coraknya seperti : Madrasah Al Banat di kota Jambi dan Madrasah Tarbiyah Islamiyah di Muaro Tebo. ${ }^{15}$

Para santri yang belajar di sana berasal dari daerah Kampung Tengah, Jelmu, Mudung Laut, Takhtul Yaman, Olak kemang, Tanjung Pasir, dan Ulu Gedong. Selain itu juga ada santri yang berasal dari luar Jambi seperti; Sorolangun, Rengat, Tembilahan, Riau Daratan, dan Pelembang. Lulusan dari Madrasah di atas banyak yang menjadi tokoh agama, mengajar sebagai guru agama, dan ada juga yang melanjutkan pendidikan ke Timur Tengah. ${ }^{16}$

${ }^{14}$ Ali Muzakir, Pemikiran Islam di Jambi: Memperkuat Kajian Islam Melalui Naskah-Naskah Lokal (Jambi: Sultan Thaha Press IAIN STS, 2011), 16.

15 A. Ibrahim Rauf, Pembaharuan Pendidikan Islam di Jambi (Telaah Corak Pendidikan Pada Madrasah As'ad Jambi Sebrang) (Jambi: IAIN STS Jambi, 1998), 12.

${ }^{16}$ Murakir, Pemikiran Islam di Jambi: Memperkuat Kajian Islam Melalui Naskah-Naskah Lokal, 88.
Dalam implementasinya, madrasah tradisional ini melakukan sistem pembelajaran Islam yang bersumber dari kitab-kitab karya ulama klasik periode abad ke-8 sampai abad ke13. Ilmu-ilmu keislaman yang dipelajari adalah ilmu syari'ah, akidah, tafsir, hadits, tasawuf, akhlak, bahasa, dan logika. Ilmu-ilmu tersebut dipelajari melalui kitab-kitab kuning secara tradisional melalui bimbingan kyai dengan sistem halaqoh. Yaitu murid menerima pembelajaran dengan berkumpul dalam satu ruangan sambil duduk bersila dan mendengarkan guru membaca kitab. ${ }^{17}$

Sesuatu yang menarik dari pendidikan Islam di Jambi apabila dibandingkan dengan Perkembangan pendidikan Minangkabau di dakade yang sama. Masyarakat Minangkabau mendapatkan pendidikan Islam di surau yang juga menjadi bagian dari bagian lembaga yang ada di tiap nagari. Sedangkan di Jambi pendidikan Islam sudah didapatkan masyarakat di Madrasah tradisional yang dipelopori ulama dari Jambi yang menyelesaikan pendidikan Islam Mekah. ${ }^{18}$

Sistem pendidikan islam pertama didirikan di Jambi adalah madrasah tradisional dengan sistem halaqoh. Nama "Madrasah" sebagai lembaga pendidikan Islam pertama di Jambi berakar dari timur tengah.

Hal ini dikarenakan banyak ulama-ulama Jambi yang menempuh pendidikan di Timur Tengah, sehingga mereka terinspirasi dengan sistem pendidikan yang diterapkan di Timur Tengah. Pendidikan Islam di Timur Tengah, madrasah merupakan pengembangan pendidikan islam yang berpusat di mesjid yang awalnya adalah pembelajaran al-qur'an melalui halaqah dan kuttab. Namun, berbeda halnya

17 Muhamad Akip Sarkowi, "Kulturasi Ajaran Islam Melalui Sistem dan Lembaga Pendidikan Islam Pada Masyarakat Masa Kesultanan di Nusantara," Sindang 1, no. 2 (2019): 96.

18 Azyumardi Azra, Surau, Pendidikan Islam Tradisional dalam Transisi dan Modernisasi Jakarta: PT. Logos Wacana Ilmu, 2003). Hal. 34 
dengan yang diterapkan di Jambi. Sistem pembelajaran madrasah tidak dilaksanakan di mesjid tetapi di ruangan yang luas dengan sistem halaqah. ${ }^{19}$

Perkembangan pendidikan islam begitu diminati oleh masyarakat Jambi. Sehingga Belanda membuat kebijakan untuk mengaturnya. Kebijakan itu tertuang dalam ordonasi guru yang dikeluarkan pertama kali pada tahun 1905 yang mana memberi kewajiban bagi setiap orang yang memberikan bagi guru agama Islam untuk meminta izin pada pemerintah Belanda. Pada tahun 1932 keluar kebijakan yang keras, yaitu pemerinh akan menutup madrasah dan sekolah yang tidak memiliki izin. ${ }^{20}$

Kebijakan ini disebut sebagai Ordonasi Sekolah (Widle School Ordonantie). Aktifitas yang berkaitan dengan pengajaran agama Islam, pemerintah membuat kebijakan yang mengacu kepada dua prinsip, yaitu : tidak membenarkan pengajaran agama pada sekolah pemerintah dan tidak dibenarkan memberikan tambahan pelajaran agama kecuali sepengetahuan dan izin dari orang tua. ${ }^{21}$

\section{Penggunaan Syair dalam Proses Pendidikan Islam di Jambi}

Syair dalam pendidian Islam Jambi Seberang dalam penyampaiannya merupakan sebuah karya sastra yang diciptakan pengarangnya dari wujud ekspresinya. Salah satu unsur yang turut membangun terciptanya sebuah syair adalah lingkungan sosial tempat syair itu berasal.

Kondisi ini berhubungan dengan kehidupan dalam lingkungan sosial tersebut. Membentuk satu lingkup sosial dengan pengaruh adat tradisional yang kokoh, menjadi salah satu unsur lahirnya syair-syair

${ }^{19}$ Hasan Basri Agus, Pejuang Ulama dan Ulama Pejuang Negeri Melayu Jambi (Jambi: Pusat Kajian Pengembangan Sejarah dan Budaya Jambi, 2012), 12.

20 Mahmud Yunus, Sejarah Pendidikan Islam di Indonesia (Jakarta: Hidakarya Agung, 1996), 45. yang cenderung menempatkan ciri khas yang unik. $^{22}$

Salah satunya dengan membuat pola pembelajaran yang disesuaikan dengan karekteristik masyarakat yaitu bersenandung dengan polarisasi seperti berselokoh dalam kehidupan sehari-hari. Pendekatan ini juga dilakukan pada ruang lingkup pendidikan yang masuk ke Jambi dengan mengunakan metode Syair didalam. Keadaan ini dilakukan agar bentuk pemhaman ilmu agama Islam bisa di pelajari dengan baik dalam kehidupan seharihari.

Pada abad-20an para tuan guru madrasah yang ada di Jambi Seberang mejadi motor penggerak syair berkembang dalam dunia pendidikan. Ini merupakan cara yang dilakukan untuk memudahkan pembelajaran agama dapat dipahami dan dilaksanakan secara luas bagi masyarakat. Syair dalam dunia pendidikan Jambi Seberang paruh awal abad 20 didominasi untuk pengenalan pelajaran agama yang dasar dan digunakan untuk pembelajaran seperti dalam pelajaran tauhid, dan lainnya.

Kondisi ini dilakukan agar pemahaman hapalan yang dilakukan dapat selalu ingat dengan metode ini. Syair dalam pendidikan madrasah Jambi Seberang sudah didahului oleh para tuan guru yang mengajar di madrasahmadrasah dalam Perkumpulan Samratu Inshan. Walaupauan berbeda madrasah tetapi para tuan guru yang mengajar di madrasah mereka masing-masing mengajarkan metode dan cara yang sama.

Agar murid- murid dapat mengerti apa yang dipelajari dalam penyampaian syair tersebut. Para murid yang dalam pembelajarannya menggunakan metode syair akan makin tambahan pemahamannya. Metode

${ }^{21}$ Masitoh, “Tsamaratul Insan dan Pengembangan Pendidikan Islam di Kota Jambi (19151972M)," 74.

${ }^{22}$ Fitri Merawati Yosi Wulandari, Wachid Eko Purwanto, "Petuah Tentang Syariat dalam Syair Sidi Djamadi," Deiksis 6, no. 1 (2019): 57. 
ini juga dilakukan murid yang tamat dalam proses pengajarannya.

Dari sekian banyak itu yang sangat produktif mengembangkan dan menulisakan karya syair itu adalah Tuan guru Abdul Qodir Ibrahim. Tuan guru Abdul Qodir Ibrahim merupakan salah satu ulama Jambi yang sangat konsen menelurkan karya-karya syairnya.

Tuan Guru Abdul Qadir bin Ibrahim atau dikenal oleh masyarakat Jambi dengan Guru Qodir (keramat), lahir di Kampung Tengah Jambi pada tanggal 18 Shafar $1332 \mathrm{H}$ atau 1914 M dan wafat pada waktu shubuh Jum'at 10 Juli 1970 di Jakarta. Nama lengkap beliau adalah Abdul Qadir Jaelani bin Guru Ibrahim bin Syeh Abdul Majid (Jambi) yang diberikan ayahnya untuk mengenang kakeknya yang meninggal dalam perjalanan pulang berziarah dari makam Syekh Abdul Qadir Jaelani. ${ }^{23}$

Pengetahuan agama yang beliau dapat diantaranya dari ayahnya dan dari madrasah yang didirikan ayahnya sendiri Guru Ibrahim bin syeh Abdul Majid ; yaitu Madrasah Nurul Iman ulu gedong Jambi, dan beliau juga mengaji antara lain kepada Syekh Hasan al-Yamany (Mufti Mekkah) guna memperdalam ilmu Fiqh dan Ushul Fiqh pada tahun 1939, Syekh Ali Maliky (Mufti Mekkah) 1939 dan Syekh 'Arif guna memperdalam ilmu Falak pada tahun 1936.

Sejak umur 13 tahun beliau telah aktif mengajar di Madrasah Nurul Iman Ulu Gedong. Pada tahun 1943-1944 beliau sebagai Raisul Mu'allimin dan pada tahun 1944-1948 atau disaat berumur 30 tahun beliau diangkat sebagai Mudhir (Pimpinan) madrasah Nurul Iman ulu gedong Jambi tersebut, menggantikan mudhir - mudhir sebelumnya, diantaranya ayahnya sendiri Guru Ibrahim bin syeh Abdul Majid, Guru Khop Tua, dan Syeh Mahmud Al bukhari.

23 Bakar, "Pendidikan Islam di Jambi: Corak Madrasah dari Kebudayaan Masyarakat Seberang Kota Jambi." 36
Beliau mempunyai cita-cita untuk meningkatkan sistem pendidikan secara modern di Jambi. Hal ini beliau terapkan dengan mendirikan pengajian di Langgar Putih pada tahun 1948 yang merupakan awal sejarah berdirinya lembaga pendidikan Islam yang modern di Jambi yaitu Perguruan Pondok Pesantren As'ad yang berlokasi di Kompleks Pondok Pesantren As'ad Olak Kemang Jambi. Di tempat ini pula beliau mendirikan Fakultas Tarbiyah dan Ushuluddin pada tahun 1964 atau 1965 yang kemudian menjadi IAIN Sultan Thaha Saifuddin dan jabatan dekan beliau pegang sampai akhir hayatnya.

Karya beliau yang sampai saat ini masih diajarkan di madrasah-madrasah yang ada di Jambi seperti : Syair Dalam Kitab Mughnil Awam, Syair Kitab Riyadhus Shibyan, Syair AlHuiriyah, dan Syair al-Madrsatul As'ad.

Syair dalam Kitab Mughnil Awam, Bait syairnya dalam bahasa melayu yang mengandung dasar dasar ajaran Islam yang beliau simpulkan dari kitab-kitab besar dan di transformasi kedalam budaya masyarakat jambi agar lebih mudah diingat dan dipahami oleh anak anak dan seluruh lapisan masyarakat. ${ }^{24}$

Mughnil 'Awâm. Kitab ini berisi tentang ajaran tauhid seperti rukun Islam, rukun iman, dan nama-nama nabi yang ditulis dalam bentuk sya'ir. Bahasa yang digunakan adalah Melayu dengan aksara Arab Melayu. ${ }^{25}$

Jumlah sya'ir seluruhnya ada 79 bait, kitab ini disusun pada bulan Jumadil Ula 1369 H. kitab ini merupakan kitab teks yang dipelajari di madrasah As'ad sampai sekarang. Kitab ini merupakan kitab elementer bagi pemula atau anak-anak dalam mempelajari ilmu tauhid.

${ }^{25}$ Abdul Qodir Ibrahim, Kitab Mughnil Awwam, Madrasah Asad Tahun 1949 (Jambi: Kantor Kementrian Agama Kota Jambi, 2010), 34. 


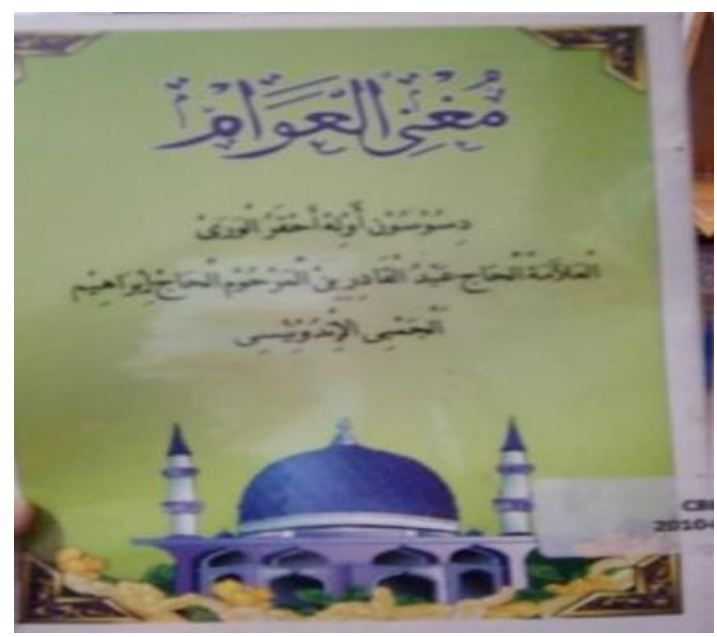

Gambar 1: Kitab Syair Mughnil ‘Awâm

Karya syair selanjutnya yaitu kitab syair Riyadhus Shibyan, kitab ini berisi dasar-dasar ilmu Nahwu. Kitab ini merupakan kitab yang wajib dihafalkan oleh para santri madrasah As'ad yang baru mulai mempelajari ilmu Nahwu. Kitab ini sampai sekarang tetap dipelajari dan digemari oleh para santri madrasah As'ad karena kitab ini berbahasa Arab Melayu yang disusun dengan bait-bait syair. Metode mempelajari dan menghafal kitab ini dengan cara dilagukan (dinyayikan), sehingga para santri pemula tidak bosan dalam mempelajari ilmu Nahwu dan memahami kitab dasar-dasar ilmu Nahwu berbahasa Arab.

Syair ini digunakan untuk dapat mempertajam daya ingat dalam mempelajari pelajaran bahasa arab bagi para murid Tuan guru Abdul Qadir Ibrahim, dan pembelajaran dalam bahasa arab semakin mudah untuk di pahami dalam pembelajarannya.

Selain dua kita tersebut satu karya yang syair Tuan Guru Abdul Qodir Ibrahim Yaitu Syair Al-Huiriyah. Syair ini dibuat pada masa perjuangan Jambi melawan Kolonial belanda. Semangat syair ini dibuat untuk mengobarkan semangat santri untuk berjuang melawan dan memperjuangkan bela tanah air Jambi dari segala bentuk penjajahan. Pengobaran semangat yang dibuat oleh Tuan Guru Abdul Qodir Ibarahim sangat jelas dalam syair ini yaitu dalam bait syair nya yang menyatakan kemerdekaan untuk berjuang dan selalu harus bela tanah air.

Penyampain syair ini dilakukan kepada murid-murid beliau dan masyarakat luas. Beliau membuat syair ini masa perjuangan rakyat Jambi melawan militer Belanda. Hal ini dilakukan dengan mengobarkan dan memberi semangat bagi rakyat Jambi untuk berjuang.

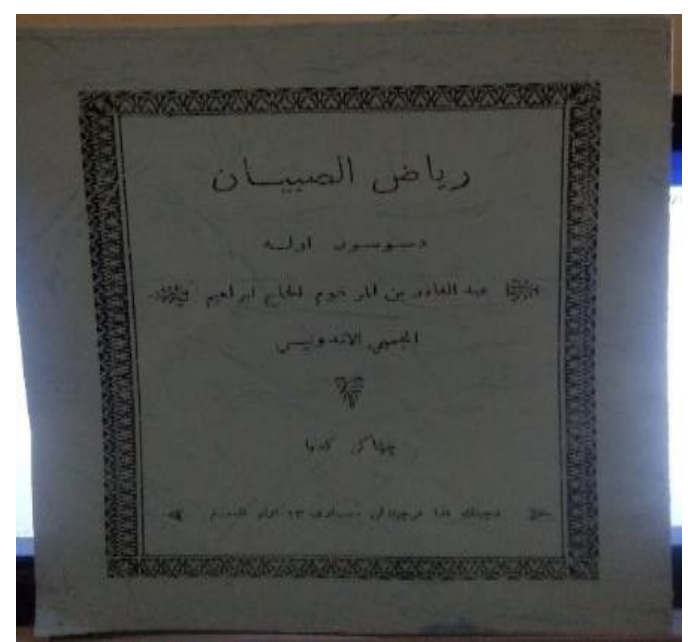

Gambar 2: Kitab Syair Al-Huiriyah

Penyampaian syair ini dilakukan agar didengar dan bisa dihayati untuk berjuang melawan belanda. Syair yang diciptakan oleh tuan guru Abdul Qodir Ibrahim yaitu AlHuriyyah, yang memiliki makna kemerdekaan. Lagu ini diciptakan dengan tujuan memberi motivasi para santri, membangun rasa kebersamaan, dan cinta tanah air. Syair ini ditulis beliau pada tahun 1944 M sebelum kemerdekaan Indonesia diproklamirkan.

Sampai sekarang syair ini tetap dikumandangkan di madrasah As'ad dalam memperingati hari kemerdekaan bangsa Indonesia tanggal 17 Agustus setiap tahunnya. Sebagaimana yang dikatakan oleh bapak Najmi Qodir berikut ini:

"Beliau ada juga mengarang lagu yang bejudul al-kwariyah yang artinya kemerdekaan. Disitu di dalam lagu itu pemikiran-pemikaran beliau diantaranya 
bahwa Indonesia ini adalah sebuah republik dan negara kesatuan"26

Syair berikut ini bisa dilagukan di Pondok Pesantren As'ad Jama pada masa Perjuangan Kemerdekaan Republik Indonesia. Tetapi kemudian di masa setelah merdeka, syair ini tetap diajarkan di pesantren untuk menumbuhkan kecintaan pada tanah air untuk para anak didik.

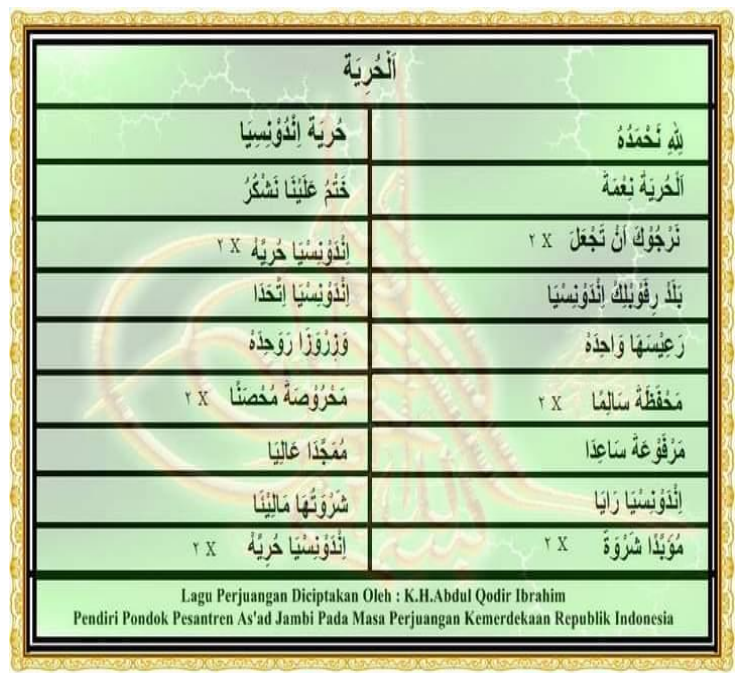

Gambar 3: Syair Al-Huriyyah

\section{Artinya:}

Kami bersyukur pada Allah

Atas ni'mat kemerdakaan

Kami berbarap kepada engkan agar menjadikan $2 x$ negara republik Indonesia

Presiden/pemimpinnya satu

Yg menjaga keselamatan/ketentraman 2x

Yg menjunjung tinggi kebahagiaan

Indonesia raya

Selamanya tetap berkobar $2 x$

Indonesia merdeka

Sbg tanda rasa syukur kami

Indonesia merdeka $2 x$

Indonesia bersatu

Saling menjunjung tinggi

Yg terjaga / dibentengi $2 x$

Yg memulyakan / dimulyakan

Mengisi kobaran semangat
Indonesia merdeka $2 x^{27}$

Karya syair yang lain berupa kecintaannya kepada madrasah tempat pendidikan agama yang beliau dirikan sendiri yaitu Madrasah As'ad. Syair al-Madrsatul As'ad beliau buat. Beliau menciptakan syair ini untuk bersama sama menjaga pendidikan agama ini selalu dijaga dan dipelajari dari generasi yang selalu belajar agama.

KH. Abdul Qodir juga mengarang syair yang berjudul Al-Madrsatul As'ad. Syair ini merupakan syair yang beliau buat di Madrsah As'ad, yang dinyanyikan para guru dan santri madrasah As'ad setiap hari sebelum memasuki kelas masing-masing. Syair ini berisi doa-doa agar para santri dan guru ilmu dan mengamalkan ilmu, serta bermanfaat bagi masyarakat dan bahagia dunia akhirat. Berikut ini bait-bait lagu mars As'ad.

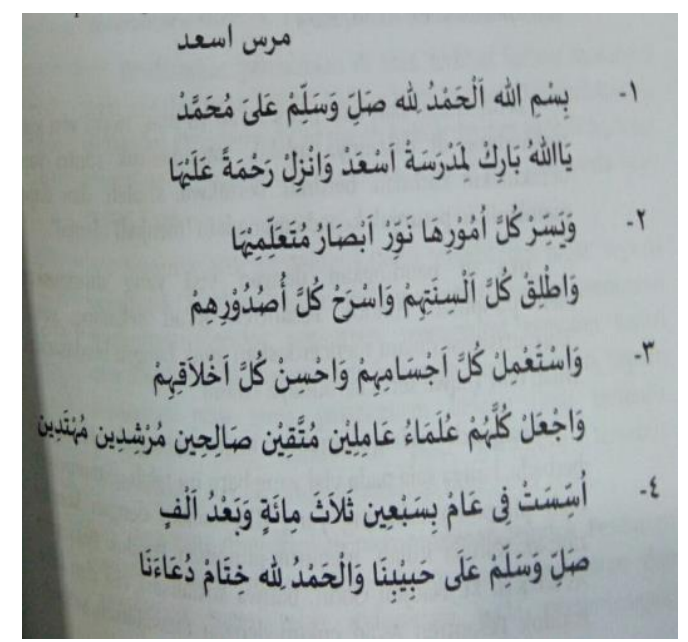

Gambar 4: Syair Al-Madrsatul As'ad

Artinya:

1 Dengan nama Allah dan Syukur pada-Nya, sholawat beserta salam atas Nabi Mubammad SAW, Ya Allah berilab berkat kepada Pondok Pesantren As'ad serta turunkanlab rabmat padanya.

2 Ya Allah, permudablab segala urusannya, terangilab penglihatan yang menuntut ilmu dengannya, perlancarlah segala ucapan bagi mereka, dan lapangkanlah dada mereka

\footnotetext{
${ }^{27}$ Fajri Al-Mughni (Guru) Wawancara, 3 Mei 2019.
} 
3 Ya Allab berikanlah kesehatan kepada yang menuntut ilmu padanya, baguskanlah semua akblak-akblak. mereka dan jadikanlah mereka menjadi ulama yang mengamalkan ilmunya, orang-orang yang bertakwa, sholeh, orang yang memberi petunjuk dan diberi petunjuk.

4 Sholawat dan salam teruntuk kepada kekasih kami Muhammad dan segala puji bagi Allah

\section{Kesimpulan}

Pendidikan Jambi seberang yang di sebut serambi mekahnya wilayah Jambi menjadi magnet pendidikan Islam di abad ke 20 yang sangat tersohor keberadaannya. Wilayah yang berada di pinggiran sungai merupakan penghasil para ulama dan orang terpandang di Jambi atau di luar Jambi. Penggunaan ajaran Islam yang dilakukan Tuan Guru madarasah yang ada di Jambi Seberang menggunakan syair dalam pendekatannya. Kondisi ini semakin membuat kasanah pendidikan di Jambi semakin berwarna.

Para tuan guru mengunakan metode syair dalam pendidikan Metode mengajarkan syair baik dalam bentuk yang berupa pantun maupun berselokoh, dan lain nya disesuaikan dengan masyarakat Jambi. Dalam pengajaran dan berdakwah mengajar murid murid yang ada di madrasah-madarasah penggunaan metode syair dilakukan mulai dari pembelajaran mengenai ilmu agama Islam yang mendasar sampai yang berat kajiannya. Metode syair juga digunakan dalam proses belajar seperti dalam mata pelajaran bahasa arab. Penggunaaan syair dalam proses sering sekali digunakan. ${ }^{28}$

Salah satu tuan guru yang punya kontribusi dalam syair di pendidikan madrsah Jambi Seberang yaitu tuan guru Abdul Qodir Ibrahim. Tuan guru ini banyak membuat karya yang fundmental dalam syairnya. Mulai dari pengguananan syair dalam proses belajar di madrsah sampai syair yang digunakan dalam mengobarkan semangat perjuangan.

\footnotetext{
${ }^{28}$ Ramzi Sulaiman (Guru) Wawancara, 1 Juni 2019
}

Metode pembelajaran syair abad $20 \mathrm{di}$ Jambi pada masa itu efektif digunakan. Efektivitasnya dapat dilihat dengan penggunaan syair ini berupa ajaran Islam yang sangat diresapi dalam kehidupan sehari-hari. Syairsyair yang dibuat pundi sesuaikan dengan kondisi seperti, dalam musyawarah masyarakat, menasehati dalam prosesi pernikahan, sampai dalam kegitan menidurkan anak pun dapat dilakukan. Syair tersebut tampaknya secara pelan dan pasti masuk kehati para pendengarnya, sehingga kapan pun akan selalu diingat dan diamalkan ajaran yang telah didapat.

\section{Daftar Kepustakaan}

Adrianus Chatib, Dkk. Kesultanan Jambi dalam Konteks Sejarah Nusantara. Jambi: Puslitbang Lektur dan Khazanah Keagamaan Badan Litbang dan Diklat Kementrian Agama RI dan Fakultas Adab IAIN Sultan Taha Saifuddin, 2011.

Agus, Hasan Basri. Pejuang Ulama dan Ulama Pejuang Negeri Melayu Jambi. Jambi: Pusat Kajian Pengembangan Sejarah dan Budaya Jambi, 2012.

Aliyas. "Meninjau Kembali Sejarah Masuknya Islam di Jambi. Media Akademika" 28, no. 3 (2013): 12.

Azra, Azyumardi. Surau, Pendidikan Islam Tradisional dalam Transisi dan Modernisasi. Jakarta: PT. Logos Wacana Ilmu, 2003.

Bakar, Abu Usman. "Pendidikan Islam di Jambi : Corak Madrasah dari Kebudayaan Masyarakat Seberang Kota Jambi." Disertasi PPS LAIN Syabid Jakarta, 1985, 35.

F, Soerjono Seokanto. Sosiologi Suatu Pengantar. Jakarta: Rajawali Press, 1985.

Hartono Margono, Mujilan, J.R. Chaniago. Sejarah Sosial Jambi: Jambi Sebagai Kota Dagang. Jakarta: Departemen Pendidikan dan Kebudayaan, 1984.

Ibrahim, Abdul Qodir. Kitab Mughnil Awwam, 
Madrasah Asad Tahun 1949. Jambi: Kantor Kementrian Agama Kota Jambi, 2010.

Ika Selviana, Hendra Irawan. "Nilai Nilai Moral dalam Syair Cinta Rasul Al-Busiry." Jurnal Al-Fathin 3 (2020).

Isma, As'Ad. "Pergeseran Peran Sosial Tuan Guru dalam Masyrakat Jambi Seberang." Kontekstual Jurnal Penelitian Sosial Keagaman 20 (2005): 6.

Lihat Lindayanti, H. Junaidi T. Noor, Ujang Hariadi. Elsbeth Locher-Scholten, Sumatraans Sultanaat En Koloniale Staat: De Relatie Djambi- Batavia (1830-1907) En Het Nederlandsche Imperialisme. Leiden: KITLV, 1994.

M.A.P.Meilink-Roelofsz. Perdagangan Asia dan Pengaruh Eropa di Nusantara Antara 15001630, Diterjemabkan Oleb Aditya Pratama. Yogyakarta: Ombak, 2016.

Masitoh. "Tsamaratul Insan dan Pengembangan Pendidikan Islam di Kota Jambi (1915- 1972M)." Thesis UIN Sunan Kalijaga Yogyakarta, 2018.

Muzakir, Ali. Pemikiran Islam di Jambi: Memperkuat Kajian Islam Melalui NaskahNaskah Lokal. Jambi: Sultan Thaha Press IAIN STS, 2011.

Rauf, A. Ibrahim. Pembaharuan Pendidikan Islam di Jambi (Telaab Corak Pendidikan Pada Madrasah As'ad Jambi Sebrang). Jambi: IAIN STS Jambi, 1998.

Roqib, Moh. Ilmu Pendidikan Islam: Pengembangan Pendidikan Integratif di Sekolah, Keluarga dan Masyarakat. Yogyakarta: LKIS, 2009.

Sarkowi, Muhamad Akip. "Kulturasi Ajaran Islam Melalui Sistem dan Lembaga Pendidikan Islam pada Masyarakat Masa Kesultanan di Nusantara." Sindang 1, no. 2 (2019).

Sjamsuddin. Metodologi Sejarah. Jakarta: Departemen Pendidikan dan Kebudayaan Direktorat Jenderal Pendidikan Tinggi, 1996.

Yosi Wulandari, Wachid Eko Purwanto, Fitri Merawati. "Petuah tentang Syariat dalam Syair Sidi Djamadi." Deiksis 6, no. 1
(2019).

Yunus, Mahmud. Sejarah Pendidikan Islam di Indonesia. Jakarta: Hidakarya Agung, 1996.

Ika Selviana, Hendra Irawan. "Nilai Nilai Moral dalam Syair Cinta Rasul Al-Busiry." Jurnal Al-Fathin 3 (2020).

Isma, As'Ad. "Pergeseran Peran Sosial Tuan Guru dalam Masyrakat Jambi Seberang." Kontekstual Jurnal Penelitian Sosial Keagaman 20 (2005): 6.

Lihat Lindayanti, H. Junaidi T. Noor, Ujang Hariadi. Elsbeth Locher-Scholten, Sumatraans Sultanaat en Koloniale Staat: De Relatie Djambi- Batavia (1830-1907) en Het Nederlandsche Imperialisme. Leiden: KITLV, 1994.

M.A.P.Meilink-Roelofsz. Perdagangan Asia dan Pengaruh Eropa di Nusantara Antara 15001630, Diterjemabkan Oleh Aditya Pratama. Yogyakarta: Ombak, 2016.

Masitoh. "Tsamaratul Insan dan Pengembangan Pendidikan Islam di Kota Jambi (1915- 1972M)." Thesis UIN Sunan Kalijaga Yogyakarta, 2018.

Muzakir, Ali. Pemikiran Islam di Jambi: Memperkuat Kajian Islam Melalui NaskabNaskah Lokal. Jambi: Sultan Thaha Press IAIN STS, 2011.

Rauf, A. Ibrahim. Pembaharuan Pendidikan Islam di Jambi (Telaab Corak Pendidikan pada Madrasah As'ad Jambi Sebrang). Jambi: IAIN STS Jambi, 1998.

Roqib, Moh. Ilmu Pendidikan Islam: Pengembangan Pendidikan Integratif di Sekolah, Keluraga dan Masyarakat. Yogyakarta: LKIS, 2009.

Sarkowi, Muhamad Akip. "Kulturasi Ajaran Islam Melalui Sistem dan Lembaga Pendidikan Islam pada Masyarakat Masa Kesultanan di Nusantara." Sindang 1, no. 2 (2019).

Sjamsuddin. Metodologi Sejarah. Jakarta: Departemen Pendidikan dan Kebudayaan Direktorat Jenderal Pendidikan Tinggi, 1996.

Yosi Wulandari, Wachid Eko Purwanto, Fitri Merawati. "Petuah Tentang Syariat dalam 
Syair Sidi Djamadi." Deiksis 6, no. 1 Wawancara

(2019).

Yunus, Mahmud. Sejarah Pendidikan Islam di Indonesia. Jakarta: Hidakarya Agung, 1996.
Najmi Qodir (Guru), wawancara, 1 Mei 2019

Fajri Al-Mughni (Guru), wawancara, 3 Mei 2019

Ramzi Sulaiman (Guru), wawancara, 12 Juni 2019 